\title{
Bacillus subtilis TR47II as a source of bioactive lipopeptides against Gram-negative pathogens causing nosocomial infections
}

\author{
Fernanda de Souza Freitas ${ }^{1}$ (D) . Tiago Coelho de Assis Lage ${ }^{1} \cdot$ Bruna Almeida Leão Ayupe $^{1}$. \\ Tatiane de Paula Siqueira ${ }^{1} \cdot$ Mariana de Barros ${ }^{2} \cdot$ Marcos Rogério Tótola ${ }^{1}$
}

Received: 19 June 2020 / Accepted: 28 September 2020 / Published online: 13 October 2020

(c) King Abdulaziz City for Science and Technology 2020

\begin{abstract}
This study aimed to investigate the antimicrobial, antibiofilm, and cytotoxic effects of biosurfactant lipopeptides synthesized by Bacillus subtilis TR47II. For this purpose, the lipopeptides were partially purified using a three-step process and characterized. In the first step, the crude extract obtained from acid precipitation exhibited strong antibacterial activity against the Gram-negative opportunistic pathogens Alcaligenes faecalis ATCC 8750, Achromobacter xylosoxidans ATCC 13138, Pseudomonas alcaligenes ATCC 14909, and Pseudomonas putida ATCC 15175. Moreover, partial inhibition was observed against Klebsiella aerogenes ATCC 13048 (42\%), Escherichia coli ATCC 25922 (16\%), and Pseudomonas aeruginosa ATCC 27853 (47\%). The lipopeptides in the crude extract were extracted with methanol and fractioned on a silica gel chromatography column, rendering four TLC-pooled chromatographic fractions, named F1, F2, F3, and F4. The chromatographic fraction F4 was the most bioactive, with MIC values between 300 and $600 \mu \mathrm{g} \mathrm{mL}^{-1}$. Besides, F4 at sub-MIC doses dislodged the biofilms of A. faecalis, A. xylosoxidans, and P. alcaligenes by about 100,85 , and $81 \%$, respectively. No cytotoxic effect was observed in mammalian cells at MIC. MALDI-TOF-MS analysis revealed that F4 contained cyclic lipopeptides belonging to two families: iturins (m/z 1004 to 1087) and fengycins (m/z 1424 to 1545). The dual effect of F4 on planktonic and sessile growth could suggest that the synergistic application of these biosurfactants could be efficient in the control of these opportunistic pathogens.
\end{abstract}

Keywords Biosurfactants $\cdot$ Antimicrobial lipopeptides $\cdot$ Iturin $\cdot$ Fengycin

\section{Introduction}

Antibiotic resistance is one of the biggest threats to global health and food security. Infections caused by multi-drugresistant microorganisms (MDR) result in increased mortality indices, and have been associated with a heavy economic burden due to hospital stays and higher medical costs (World Health Organization 2018). Antimicrobial resistance (AMR) already causes 700,000 deaths/year and it is estimated that

Fernanda de Souza Freitas

fernandaufv@yahoo.com.br

1 Laboratório de Biotecnologia e Biodiversidade Para o Meio Ambiente, Departamento de Microbiologia, Universidade Federal de Viçosa, Peter Henry Rolfs Avenue w/n, Viçosa, Minas Gerais, Brazil

2 Laboratório de Doenças Bacterianas, Departamento de Veterinária, Universidade Federal de Viçosa, Peter Henry Rolfs Avenue w/n, Viçosa, Minas Gerais, Brazil
10 million deaths due to AMR will occur every year after 2050 , with an associated economic loss of $\$ 100$ trillion for the global economy (O’Neill 2014; Tran et al. 2015; World Health Organization 2016; Tagliabue and Rappuoli 2018). Therefore, it is of primary importance to discover new natural antimicrobial agents to overcome AMR.

Among the diverse array of available antimicrobial biomolecules, the lipopeptides have received considerable attention for drug-lead prospection (Loiseau et al. 2015). In the last decades, some molecules from this class, such as daptomycin and polymyxin $\mathrm{B}$, have been approved by the Food and Drug Administration Agency (FDA) for the treatment of multi-drug resistant pathogen infections. Polymyxin B is now being used as the last therapeutic option for infections caused by multi-drugresistant (MDR) 'superbugs' as Pseudomonas aeruginosa, Acinetobacter baumannii, and Klebsiella pneumoniae (Cochrane and Vederas 2016). Most recently, a personal care product with anticoronaviruses activity, including 
the SARS-CoV-2, that is based on the lipopeptide surfactin (Green Butterfly-Galatec; https://www.galavon.com/) was developed. The patent PCT/CN2020/085779 will be published soon. Other commercially available antibiotic lipopeptides include caspofungin, micafungin, and anidulafungin (Mandal et al. 2013).

The genus Bacillus is known to produce various lipopeptides (e.g., surfactins, iturins, and fengycins). Several isoforms and analogs exist for these naturally produced lipopeptides, exhibiting significant structural heterogeneity. Also, this group of molecules has been extensively studied for more than 2 decades in terms of biosynthesis, isolation and purification, structure elucidation, biological activities, and mechanisms of biological activities, as well as the potential applications.

Due to the surface-active properties, lipopeptides are biotechnologically valuable in the stabilization of emulsions, dispersions, and foams, as wetting agents and in sorption or desorption processes (Moryl et al. 2015). Moreover, they show great potential in various biopharmaceutical applications due to their antimicrobial properties. These result mostly from the lipopeptides' capability to disturb the structure and functions of biological membranes, leading to the increased membrane permeability. Additionally, these amphipathic molecules modify bacterial surface hydrophobicity, stimulating the process of biofilm dispersion (Daas et al. 2018).

The strain Bacillus subtilis TR47II isolated from Trindade Island, Brazil (da Silva et al. 2015) has been characterized to co-produce surfactin, iturin, and fengycin. In this work, we investigate the antimicrobial effect of these biosurfactant lipopeptides on planktonic growth of pathogens causing nosocomial infections and biofilm eradication.

\section{Materials and methods}

\section{Microorganisms}

The biosurfactant producing bacteria Bacillus subtilis TR47II was isolated from soil samples collected from Trindade Island, Brazil (da Silva et al. 2015). The reference strains of bacteria used in the antimicrobial and antibiofilm assays were Alcaligenes faecalis ATCC 8750, Achromobacter xylosoxidans ATCC 13138, Escherichia coli ATCC 25922, Klebsiella aerogenes ATCC 13048, Klebsiella oxytoca CCT 0182, Pseudomonas aeruginosa ATCC 27853, Pseudomonas alcaligenes ATCC 14909, and Pseudomonas putida ATCC 15175 . The bacterial strains were maintained at $-80{ }^{\circ} \mathrm{C}$ in Tryptic Soy Broth (TSB) containing glycerol at $40 \%(\mathrm{v} / \mathrm{v})$.

\section{Production and partial purification of antimicrobial biosurfactant from TR47II}

An inoculum of the glycerol stock of TR47II was streaked onto a Tryptic Soy Agar (TSA) plate and incubated for $18 \mathrm{~h}$ at $30^{\circ} \mathrm{C}$. A single colony was cultured at $30^{\circ} \mathrm{C}$ and $200 \mathrm{rpm}$ for $18 \mathrm{~h}$ in $25 \mathrm{~mL}$ sterile mineral salt medium (MSM) to prepare seed cultures. The MSM used for biosurfactant production was composed of $\left(\mathrm{g} \mathrm{L}^{-1}\right): \mathrm{K}_{2} \mathrm{HPO}_{4}$ (13.9), $\mathrm{KH}_{2} \mathrm{PO}_{4}$ (2.7), yeast extract (0.05), $\mathrm{NH}_{4} \mathrm{NO}_{3}(1.0)$, and glucose (20). Trace-element composition was $\left(\mathrm{g} \mathrm{L}^{-1}\right)$ : EDTA (0.025), $\mathrm{MgSO}_{4} \cdot 7 \mathrm{H}_{2} \mathrm{O}(0.15), \mathrm{MnSO}_{4} \cdot \mathrm{H}_{2} \mathrm{O}(0.025)$, $\mathrm{NaCl}(0.5), \mathrm{CaCl}_{2} \cdot 2 \mathrm{H}_{2} \mathrm{O}(0.005), \mathrm{CoCl}_{2} \cdot 6 \mathrm{H}_{2} \mathrm{O}(0.005)$, $\mathrm{ZnSO}_{4} .7 \mathrm{H}_{2} \mathrm{O}(0.005), \mathrm{FeSO}_{4} .7 \mathrm{H}_{2} \mathrm{O}(0.005), \mathrm{CuSO}_{4} .5 \mathrm{H} 2 \mathrm{O}$ (0.0005), $\mathrm{Na}_{2} \mathrm{MoO}_{4} \cdot 2 \mathrm{H}_{2} \mathrm{O}(0.0005), \mathrm{Na}_{2} \mathrm{O}_{4} \mathrm{Se}(0.0005)$, $\mathrm{Na}_{2} \mathrm{WO}_{4} \cdot 2 \mathrm{H}_{2} \mathrm{O}(0.0005)$, and $\mathrm{NiCl}_{2} \cdot 6 \mathrm{H}_{2} \mathrm{O}(0.001)$. The $\mathrm{pH}$ of the medium was adjusted to 7.0. After seed culture preparation, an aliquot of $5 \mathrm{~mL}$ was inoculated into $1000 \mathrm{~mL}$ Erlenmeyer flasks containing $500 \mathrm{~mL}$ of MSM and cultured at $30^{\circ} \mathrm{C}$ and $200 \mathrm{rpm}$ for $120 \mathrm{~h}$.

\section{Partial purification of the biosurfactants}

The cell-free supernatant was obtained by centrifuging the culture at $10,400 \times \mathrm{g}$ for $15 \mathrm{~min}$. To precipitate the biosurfactants, the cell-free supernatant was acidified to a $\mathrm{pH}$ of approximately 2 using $\mathrm{HCl} 6 \mathrm{~N}$ and incubated overnight at $4{ }^{\circ} \mathrm{C}$. The biosurfactant crude extract was recovered by centrifugation $\left(15,000 \times \mathrm{g}\right.$ for $20 \mathrm{~min}$ at $\left.4{ }^{\circ} \mathrm{C}\right)$, solubilized in deionized water by adjusting $\mathrm{pH}$ to 7.0 with $\mathrm{NaOH} 6 \mathrm{~N}$, and lyophilized. The lyophilized powder was extracted with methanol by exhaustive extraction in Soxhlet for $12 \mathrm{~h}$, with 3-4 cycles per hour, at $60{ }^{\circ} \mathrm{C}$. The methanolic extract was concentrated using a rotary evaporator under reduced pressure. The compounds in the methanolic extract were fractioned on silica gel 60 (70-230 mesh, Sigma-Aldrich) chromatography column $(26 \times 5.0 \mathrm{~cm})$, eluting with chloroform/ methanol/water 65:25:4 and 80:25:3.5. The TLC profiling of each fraction collected from the column (individual volume $=8 \mathrm{~mL}$ ) was verified by TCL chromatography using $\mathrm{UV}_{254 \mathrm{~nm}}$ and $\mathrm{H}_{2} \mathrm{SO}_{4} 15 \%$ (v/v in ethanol) as visualizing agents. Commercial standards of the lipopeptides surfactin, iturin A, and fengycin A (1 mg mL ${ }^{-1}$, Sigma-Aldrich) were used as the reference. The samples were pooled in four fractions (F1, F2, F3, and F4) according to the retention factor $\left(\mathrm{R}_{f}\right)$ profiling. To confirm the presence of biosurfactants in the chromatographic fractions, the solvents were evaporated using a rotary evaporator under reduced pressure and the solids resuspended in water to a final concentration of $1 \mathrm{mg} \mathrm{mL}^{-1}$. The presence of surface-active compounds was detected by the oil spreading test (Morikawa et al. 2000). 


\section{Antibacterial screening and minimum inhibitory concentration (MIC)}

The inhibitory spectra of crude extract, methanolic extract, and chromatographic fractions (F1 to F4) at $1 \mathrm{mg} \mathrm{mL}^{-1}$ were determined using 96-well microtiter plates. Briefly, twofold dilutions of the compounds were prepared in Mueller-Hinton broth, and then, bacterial reference cultures at $\log$ phase were added to each well at a final density of $5 \times 10^{5} \mathrm{CFU} \mathrm{mL}{ }^{-1}$. The plates were incubated at $37^{\circ} \mathrm{C}$ for $24 \mathrm{~h}$. Bacterial growth inhibition was determined by spectrophotometric optical density (OD) at $600 \mathrm{~nm}$ in a microtiter plate reader PowerWave XS (Bio-Tek Inc.). The percentage of inhibition was calculated by the equation: where $\mathrm{A}_{0}$ is the OD of control wells (growth in absence of biosurfactants) and $A_{c}$ is the OD of the culture grown in the presence of biosurfactants:

Growth inhabition $(\%)=\left(A_{0}-A_{c}\right) / A_{0} \times 100$.

The non-inoculated wells (with and without biosurfactant) were used as negative controls.

Minimum Inhibitory Concentration (MIC) (100 to $1000 \mu \mathrm{g} \mathrm{mL}^{-1}$ ) of the most active semi-purified fraction was determined through the standard microdilution method in Mueller-Hinton broth using 96-well microtiter plates, according to the Clinical and Laboratory Standards Institute (CLSI). Briefly, $50 \mu \mathrm{L}$ of twofold stock solutions of the biosurfactants prepared in Mueller-Hinton were mixed with $50 \mu \mathrm{L}$ of bacterial reference cultures to attain a final density of $5 \times 10^{5} \mathrm{CFU} \mathrm{mL} \mathrm{m}^{-1}$. The plates were incubated at $37{ }^{\circ} \mathrm{C}$ for $24 \mathrm{~h}$ and the OD at $600 \mathrm{~nm}$ of each well was determined using a microtiter plate reader PowerWave XS (Bio-Tek Inc.). MIC was defined as the lowest concentration resulting in complete growth inhibition of the target bacteria.

\section{Biofilm removal assay}

The effect of biosurfactants on biofilm removal was evaluated according to Rautela et al. (2014). For biofilm formation, $100 \mu \mathrm{L}$ of bacterial cells suspension in Mueller-Hinton broth $\left(10^{6} \mathrm{CFU} \mathrm{mL}{ }^{-1}\right)$ were dispensed in 96-well microtiter plates, following incubation at $37^{\circ} \mathrm{C}$ for $48 \mathrm{~h}$. After biofilm formation, the supernatant was gently aspirated and the non-adhering cells were washed with PBS $(\mathrm{NaCl} 137 \mathrm{mM}$, $\mathrm{KCl} 2.7 \mathrm{mM}, \mathrm{Na}_{2} \mathrm{HPO}_{4} 8 \mathrm{mM}$, and $\mathrm{KH}_{2} \mathrm{PO}_{4} 2 \mathrm{mM}$, and $\mathrm{pH}$ 7.4). Biosurfactants' solutions prepared in Mueller-Hinton Broth (100 to $1000 \mu \mathrm{g} \mathrm{mL}^{-1}$ ) were added to the wells and the plates were incubated for $24 \mathrm{~h}$ at $37^{\circ} \mathrm{C}$. The supernatant was gently aspirated and the wells were washed with PBS. Adherent cells were fixed with $100 \mu \mathrm{L}$ of methanol $99 \%$ (v/v) for $15 \mathrm{~min}$. The biofilms were stained with $100 \mu \mathrm{L}$ of crystal violet solution $1.0 \%(\mathrm{w} / \mathrm{v})$ and washed three times with sterile distilled water. The stain adhering to the biofilms was solubilized with $100 \mu \mathrm{L}$ of acetic acid 33\% (v/v). An aliquot of $100 \mu \mathrm{L}$ of the de-staining solution was transferred to a new well and the amount of the crystal violet was measured with a microtiter plate reader PowerWave XS (Bio-Tek Inc.) at $595 \mathrm{~nm}$. Wells treated with PBS were used as blank to minimize background interference. The percentage of biofilm removal by the biosurfactants was calculated by the equation: where $A_{c}$ represents the absorbance of the wells treated with biosurfactant and $\mathrm{A}_{0}$ the absorbance of the negative control wells:

Biofilm removal $(\%)=\left(\mathrm{A}_{0}-\mathrm{A}_{\mathrm{c}}\right) / \mathrm{A}_{0} \times 100$.

For each concentration of biosurfactants tested, a negative control was prepared by adding only the biosurfactants' solutions prepared in Mueller-Hinton to empty wells.

\section{Cytotoxic effect of biosurfactants to mammalian cells}

The cytotoxic effect of antimicrobial biosurfactant was determined against mammalian cell lines. The MAC-T and Vero cells were grown in flat-bottom 96-well culture plates containing $100 \mu \mathrm{L}$ Dulbecco's Modified Eagle Medium and Modified Eagle Medium, respectively, supplemented with $10 \%(\mathrm{w} / \mathrm{v})$ fetal bovine serum, penicillin $\left(100 \mu \mathrm{g} \mathrm{mL}^{-1}\right)$, and streptomycin $\left(100 \mu \mathrm{g} \mathrm{mL}^{-1}\right)$. The plates were incubated at $37{ }^{\circ} \mathrm{C}$ at $5 \% \mathrm{CO}_{2}$ and $95 \% \mathrm{O}_{2}$ for $24 \mathrm{~h}$. Cell growth was visualized and monitored with an inverted microscope until they reached confluency (approximately $3 \times 10^{5}$ cells per well). The medium was aspirated, and the cells were washed with PBS. Biosurfactant solutions prepared in fresh media were added to the wells at the final concentrations of $1,2,4,8$, and $16 \times$ MIC (considering $\mathrm{MIC}=300 \mu \mathrm{g} \mathrm{mL}^{-1}$ ), and the plates were incubated for $24 \mathrm{~h}$. Cells not exposed to the biosurfactants served as positive growth control. Cytotoxicity was assessed using an MTT [(3-(4,5-dimethylthiazol-2-yl)2,5-diphenyltetrazolium bromide] assay. Briefly, $10 \mu \mathrm{L}$ of MTT (5 mg mL ${ }^{-1}$ in PBS, pH 7.6) were added to $100 \mu \mathrm{L}$ of media per well and incubated for $4 \mathrm{~h}$. The supernatant was discarded, and $200 \mu \mathrm{L}$ of DMSO was added to each well to dissolve the crystals. The plate was gently stirred. Absorbance was read with a spectrophotometer Titertek multiskan ${ }^{\circledR}$ Plus-MKII (Flow Laboratories, Inc.) at $550 \mathrm{~nm}$. Cells not exposed to the compound served as control.

\section{MALDI-TOF mass spectrometry analysis}

The chromatographic fraction containing the bioactive biosurfactants produced by TR47II (F4) was solubilized in ethanol $\left(2.5 \mathrm{mg} \mathrm{mL}^{-1}\right)$ and characterized by MALDI-TOF-MS.

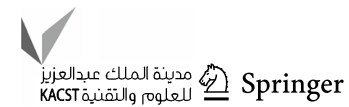


The matrix used was $\alpha$-cyano-4-hydroxycinnamic acid (Bruker Daltonics), solubilized in acetonitrile 50\% (v/v), and acidified with trifluoroacetic acid $0.1 \%(\mathrm{v} / \mathrm{v})$, to a final concentration of $10 \mathrm{mg} \mathrm{mL}^{-1}$. Then, $1 \mu \mathrm{l}$ of the sample and $1 \mu \mathrm{l}$ of the matrix were applied and homogenized at each spot of the steel plate. For calibration of the MS analysis method, standard peptides (Peptide Calibration Standard II) (Bruker Daltonics) were used. The MS spectra were acquired in an MALDI-TOF Ultraflex III (Bruker Daltonics) spectrometer employing the reflective and positive mode, with an average detection range of 500-3400 Da. All data were managed by Flexcontrol software, version 3.3 (Bruker Daltonics), and the spectra resulting from the MS were processed using the FlexAnalysis application, version 3.3 (Bruker Daltonics). Commercial standards of surfactin, iturin A, and fengycin A lipopeptides (Sigma-Aldrich) were used in a concentration of $1 \mathrm{mg} \mathrm{mL}^{-1}$ in ethanol. The spectra were analyzed based on the similarity with the spectra of commercial lipopeptide standards and based on literature (Romero et al. 2007; Pathak and Keharia 2014; Yang et al. 2015).

\section{Statistical analysis}

Data were collected from three independent experiments and the results were expressed as the mean \pm standard deviation. Statistical analyses were performed using one-way analysis of variance followed by Tukey's test at a significance level of $5 \%(p<0.05)$.

\section{Results and discussion}

\section{Biosurfactant purification}

The fractionation of the biosurfactants produced by TR47II resulted in four chromatographic fractions, F1, F2, F3, and F4. TLC profiling of the fractions has detected the presence of lipopeptides according to the $\mathrm{R}_{f}$ comparison with those from commercial standards of surfactin $\left(\mathrm{R}_{f}=0.7\right)$, iturin $\mathrm{A}$ $\left(\mathrm{R}_{f}=0.3\right)$, and fengycin $\mathrm{A}\left(\mathrm{R}_{f}=0.09\right)$. The chromatographic fractions were investigated to oil spreading activity. Table 1 summarizes the oil spreading activities and the $\mathrm{R}_{f}$ of $\mathrm{F} 1-\mathrm{F} 4$, demonstrating that $\mathrm{F} 2, \mathrm{~F} 3$, and F4 retain the surface-active properties.

\section{Antibacterial screening}

The crude extract containing biosurfactants produced by TR47II was assessed for its antibacterial activity against reference bacterial species involved in nosocomial infections. Figure 1 summarizes the antibacterial spectra of TR47II crude extract. The crude extract shows an inhibitory effect against A. xylosoxidans ATCC 13138, A.
Table 1 Oil spreading halo $(\mathrm{cm})$ of aqueous solutions $\left(1 \mathrm{mg} \mathrm{mL}^{-1}\right)$ of the chromatographic fractions $(\mathrm{F} 1-\mathrm{F} 4)$ obtained from the partial purification of biosurfactants produced by Bacillus subtilis TR47II

\begin{tabular}{lll}
\hline Chromatographic fraction & $\mathrm{R}_{f}$ & $\begin{array}{l}\text { Oil spread- } \\
\text { ing halo } \\
(\mathrm{cm})\end{array}$ \\
\hline F1 & 0.86 & $0.20 \pm 0.06$ \\
F2 & 0.72 & $9.02 \pm 1.23$ \\
F3 & $0.72 / 0.60$ & $8.33 \pm 0.61$ \\
F4 & $0.3 / 0.09$ & $2.02 \pm 0.40$ \\
\hline
\end{tabular}

The retention factors $\left(\mathrm{R}_{f}\right)$ of the spots observed in TLC for each fraction were compared with those from commercial standards of surfactin (0.7), iturin A (0.3), and fengycin A (0.09)

faecalis ATCC 8750, $P$. alcaligenes ATCC 14909, and $P$. putida ATCC 15175 . These bacterial species are frequently related to nosocomial infections that are difficult to treat due to antibiotic resistance (Treviño et al. 2010; Barragán et al. 2018; Hasan et al. 2019). Moreover, partial inhibition was observed against $K$. aerogenes ATCC 13048 (42\%), E. coli ATCC 25922 (16\%), and P. aeruginosa ATCC 27853 (47\%). Only the susceptible microorganisms were tested against the methanolic extract and chromatographic fractions. Methanolic extract and chromatographic fraction F4 at $1000 \mu \mathrm{g} \mathrm{mL}^{-1}$ were effective against all reference strains tested (Fig. 2). Fractions F1, F2, and F3 exhibited only partial inhibition.

\section{Chemical characterization of chromatographic fraction F4 by MALDI-TOF mass spectrometry}

The most active chromatographic fraction, F4, was chemically characterized by MALDI-TOF mass spectrometry. The MALDI-TOF mass spectrum of F4 revealed the presence of two separate clusters of peaks (Fig. 3a). One cluster of peaks is in the range of $1004-1087 \mathrm{~m} / \mathrm{z}$ ratio, while the other cluster of peaks in the range of 1424 to $1545 \mathrm{~m} / \mathrm{z}$ ratio. The peaks of the first range (1004 to 1087) are attributed to iturin isoforms (Romero et al. 2007; Pathak and Keharia 2014; Yang et al. 2015) and those of the second (1424 to 1545) are attributed to fengycin isoforms (Pathak and Keharia 2014; Yang et al. 2015), indicating the presence of these two classes of lipopeptides in F4.

The most intense peaks in the first range (1004 to $1087 \mathrm{~m} / \mathrm{z}$ ratio) were $\mathrm{m} / \mathrm{z} 1043.5, \mathrm{~m} / \mathrm{z} 1057.5$, and $\mathrm{m} / \mathrm{z} 1071.5$ (Fig. 3b). The molecules at $\mathrm{m} / \mathrm{z} 1043.5,1057.5$, and 1071.5 differed in their masses by 14 or multiples of $14 \mathrm{Da}\left(-\mathrm{CH}_{2}\right)$ suggesting them to be members of the same family (Pathak and Keharia 2014). The 14 Da difference observed suggested that the metabolites with $\mathrm{m} / \mathrm{z} 1043.5$ and 1057.5 and 1071.5 differed only in carbon length of $\beta$-amino acid ( $\beta \mathrm{AA})$, and are assigned as iturin A homologs 

TR47II biosurfactant crude extract $\left(1000 \mu \mathrm{g} \mathrm{mL}^{-1}\right)$ on planktonic growth of reference bacteria cultured on MuellerHinton broth. The results are expressed as a percentage of growth inhibition relative to growth positive control. Data was presented as mean \pm standard deviation of values obtained from three repetitions
Fig. 1 Effect of Bacillus subtilis

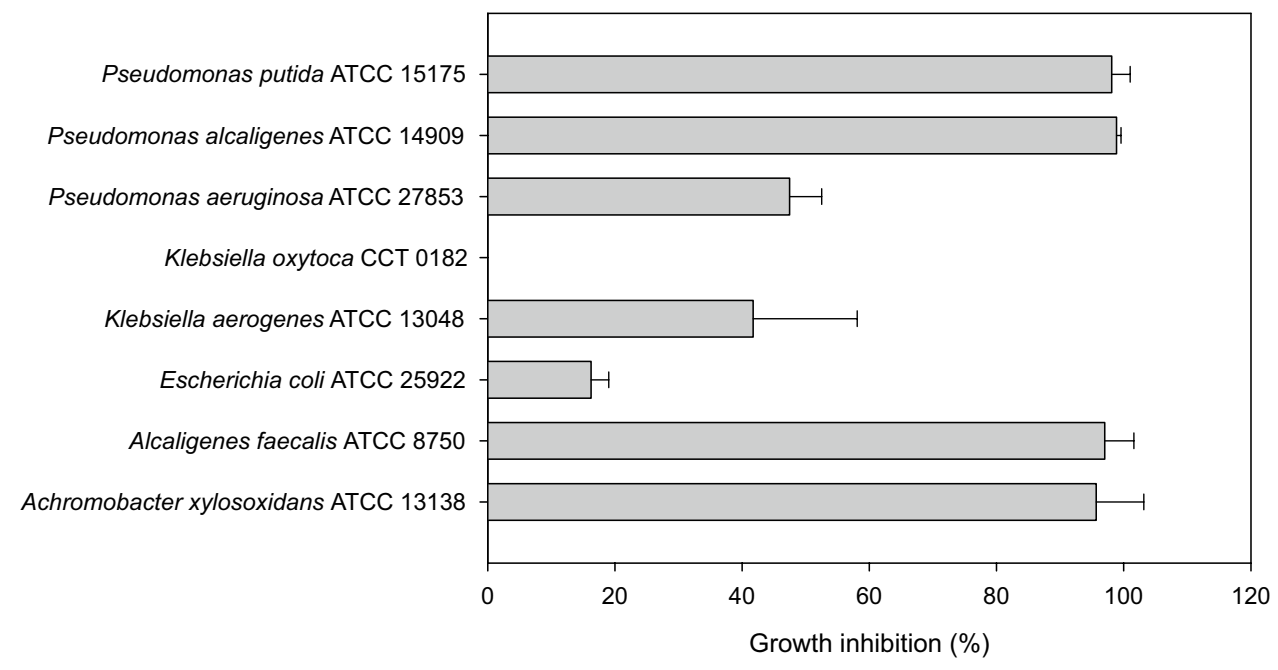

Fig. 2 Effect of Bacillus subtilis TR47II methanolic extract (ME) and chromatographic fractions (F1 to F4) at $1000 \mu \mathrm{g} \mathrm{mL}^{-1}$ on planktonic growth of a Achromobacter xylosoxidans ATCC 13138, b Alcaligenes faecalis ATCC 8750, c Pseudomonas alcaligenes ATCC 14909, and d Pseudomonas putida ATCC 15175 cultured on MuellerHinton broth. The results are expressed as a percentage of growth inhibition relative to growth positive control. Data was presented as mean \pm standard deviation of values obtained from three repetitions. Means followed by the same letter do not differ statistically by Tukey's test at $5 \%$ probability
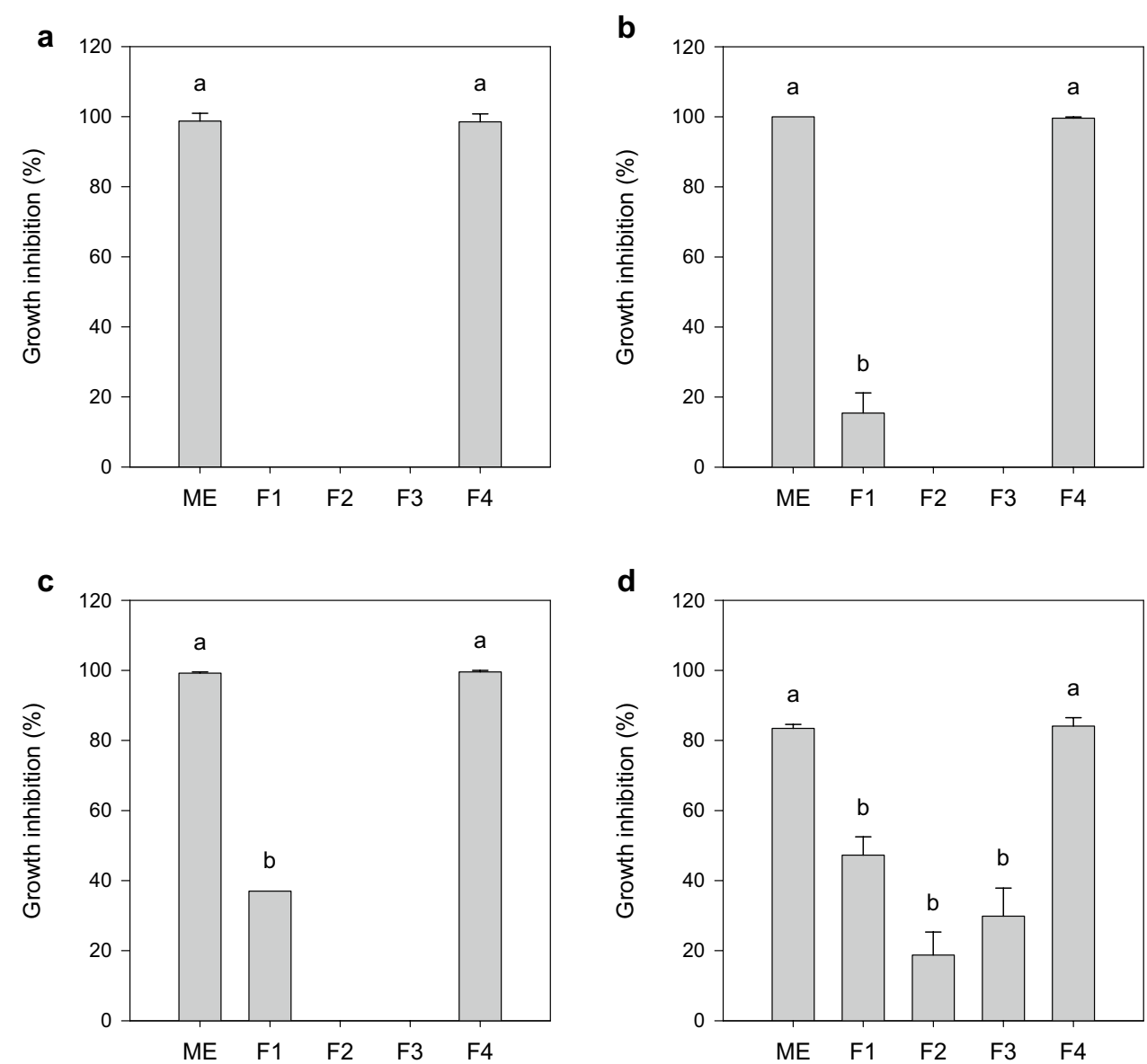

with 14- and 15- and 16-carbon $\beta$ AA, respectively (Romero et al. 2007; Pathak and Keharia 2014; Yang et al. 2015). In the second range ( 1424 to $1545 \mathrm{~m} / \mathrm{z}$ ratio), the most intense peaks were $\mathrm{m} / \mathrm{z}$ 1463.8, $\mathrm{m} / \mathrm{z} 1477.8, \mathrm{~m} / \mathrm{z} 1485.8, \mathrm{~m} / \mathrm{z} 1491.8$, $\mathrm{m} / \mathrm{z}$ 1503.8, and $\mathrm{m} / \mathrm{z} 1517.8$ (Fig. 3c). The $\mathrm{m} / \mathrm{z} 1463.8$ and 1477 peaks are assigned to fengycin (Ala-6) $[\mathrm{M}+\mathrm{H}]^{+}$ions containing $\mathrm{C} 16$ and $\mathrm{C} 17$ fatty acid chains, respectively. The $\mathrm{m} / \mathrm{z} 1495.8$ peak is assigned to fengycin $[\mathrm{M}+\mathrm{H}]^{+}$ions containing the $\mathrm{C} 17$ fatty acid chain, while the $\mathrm{m} / \mathrm{z} 1503.8$ peak is assigned to fengycin (Val-6) $[\mathrm{M}+\mathrm{Na}]^{+}$(Rautela et al. 2014; Yang et al. 2015). The size of the fatty acid chain is an important factor determining the antimicrobial spectra of lipopeptides and has been explored to improve the efficacy of these compounds and their derivatives (Nasompag et al. 
Fig. 3 MALDI-TOF mass spectra of the chromatographic fraction F4 containing bioactive biosurfactants produced by Bacillus subtilis TR47II. a Lipopeptide mass profile found in $\mathrm{F} 4$; $\mathbf{b}$ mass profile in the range of 1004 to $1087 \mathrm{~m} / \mathrm{z}$ ratio, attributed to iturins; c mass profile in the range of 1424 to $1545 \mathrm{~m} / \mathrm{z}$ ratio, attributed to fengycins. The $\mathrm{m} / \mathrm{z}$ values of peaks typical of these lipopeptides families are highlighting in bold
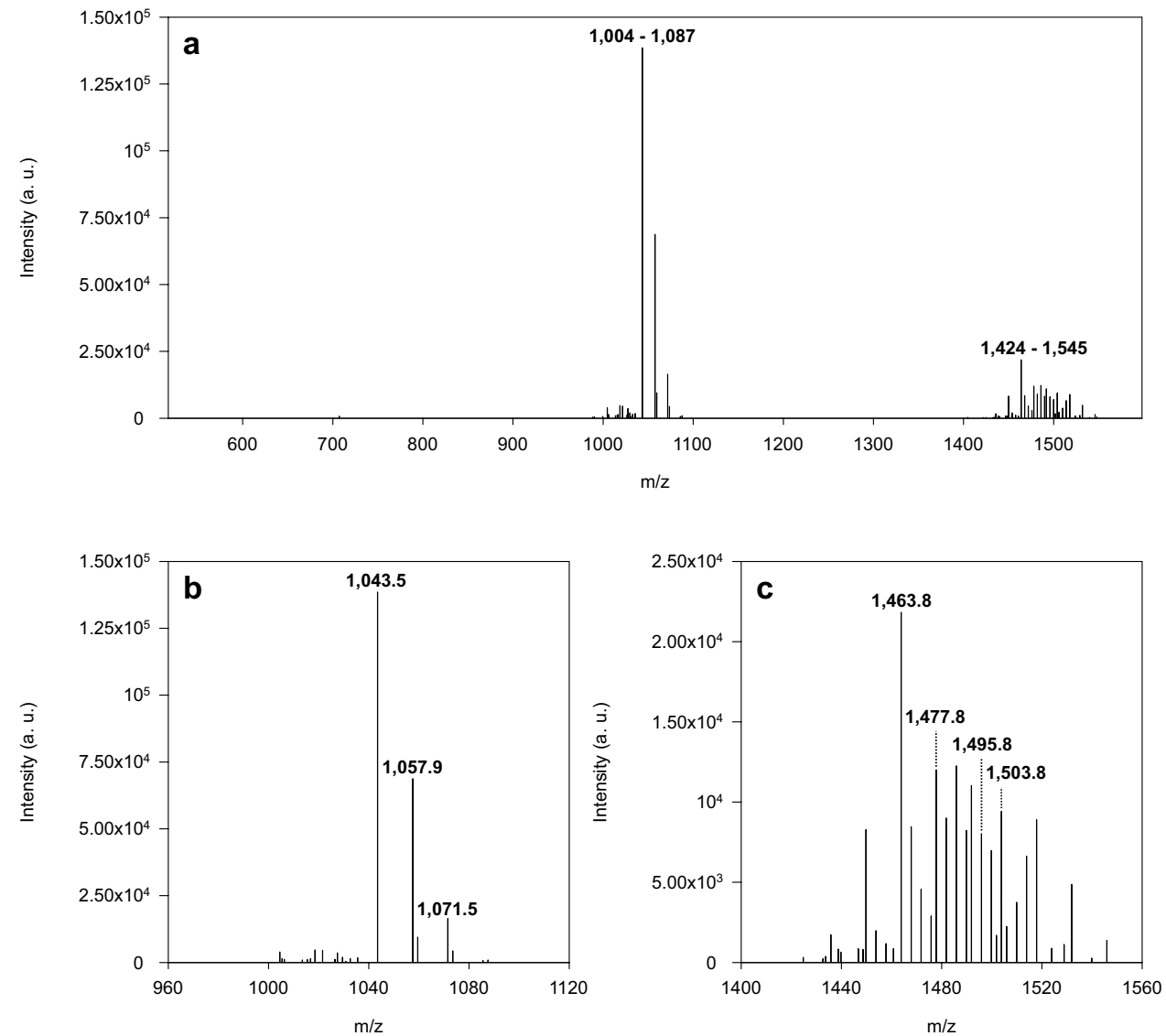

Table 2 Assignments of iturin and fengycin mass peaks obtained by MALDI-TOF mass spectrometry of chromatographic fraction F4 obtained from the partial purification of biosurfactants produced by Bacillus subtilis TR47II

\begin{tabular}{lll}
\hline Mass peak $(\mathrm{m} / \mathrm{z})$ & Assignments & References \\
\hline 1043.5 & $(\mathrm{C} 14)$ Iturin A2 $[\mathrm{M}+\mathrm{H}]^{+}$ & Romero et al. (2007), Pathak and Keharia (2014), Yang et al. (2015) \\
1057.5 & $(\mathrm{C} 15)$ Iturin A3/A4/A5 $[\mathrm{M}+\mathrm{H}]^{+}$ & Romero et al. (2007), Pathak and Keharia (2014), Yang et al. (2015) \\
1071.5 & $(\mathrm{C} 16)$ Iturin A6/A7 $[\mathrm{M}+\mathrm{H}]^{+}$ & Romero et al. (2007), Pathak and Keharia (2014) \\
1463.8 & $(\mathrm{C} 16)$ Fengycin $[\mathrm{M}+\mathrm{H}]^{+}$, Ala-6 & Yang et al. (2015) \\
1477.8 & $(\mathrm{C} 17)$ Fengycin $[\mathrm{M}+\mathrm{H}]^{+}$, Ala-6 & Yang et al. (2015) \\
1495.8 & $(\mathrm{C} 17)$ Fengycin $[\mathrm{M}+\mathrm{H}]^{+}$ & Yang et al. (2015) \\
1503.8 & $(\mathrm{C} 17)$ Fengycin $[\mathrm{M}+\mathrm{Na}]^{+}, \mathrm{Val}-6$ & Rautela et al. (2014) \\
\hline
\end{tabular}

2015). Table 2 shows the detailed assignment of dominant mass peaks of the antimicrobial lipopeptides produced by B. subtilis TR47II.

\section{Minimum inhibitory concentration (MIC)}

Distinct lipopeptide families co-produced by a single strain can exert synergic antimicrobial effect and mutually enhance their respective activities ( $\mathrm{Xu}$ et al. 2018). Moreover, the microbial strains utilized for lipopeptide production influence the composition of the compounds synthesized, which in turn can affect their antimicrobial activity (Ndlovu et al. 2017).

The minimum inhibitory concentration (MIC) of the isolated compounds in F4 against $A$. faecalis ATCC 8750, A. xylosoxidans ATCC 13138, P. alcaligenes ATCC 14909, and $P$. putida ATCC 15175 was determined using the microtiter plate method. MIC values ranged from 300 to $600 \mu \mathrm{g} \mathrm{mL}-1$ (Table 3).

Three mechanisms are proposed to describe how lipopeptides act against Gram-negative bacteria: (i) by removing $\mathrm{Ca}^{2+}$ and $\mathrm{Mg}^{2+}$ from lipopolysaccharides (LPS), leading to destabilization of the outer membrane; (ii) pore-forming 
Table 3 Minimum inhibitory concentration (MIC) of the chromatographic fraction F4 (iturin and fengycin) obtained from the partial purification of biosurfactants produced by Bacillus subtilis TR47II against susceptible reference strains

\begin{tabular}{ll}
\hline Microorganism & $\begin{array}{l}\text { Minimum inhibitory } \\
\text { concentration }(\mu \mathrm{g} \\
\left.\mathrm{mL}^{-1}\right)\end{array}$ \\
\hline Achromobacter xylosoxidans ATCC 13138 & 600 \\
Alcaligenes faecalis ATCC 8750 & 300 \\
Pseudomonas alcaligenes ATCC 14,909 & 600 \\
Pseudomonas putida ATCC 15175 & 600 \\
\hline
\end{tabular}

The values were estimated according to Clinical and Laboratory Standards Institute (CLSI) standards

(cationic channels) effect on the cell membrane, and (iii) detergency effect. Each mechanism depends on the peptide moiety, as well as on some properties of the lipidic side chain (i.e., phase, elasticity, hydrophobic chain length, and hydration) (Le Maire et al. 2000).

Fengycins are a class of cyclic lipopeptides that includes fengycin and plipastatins. These lipopeptides are broadspectrum antifungal agents, particularly effective against filamentous fungi, and possess antiproliferative activity (Cochrane and Vederas 2016). No studies have demonstrated that fengycins act as antibacterials by the mechanisms aforementioned (Patel et al. 2011; Wei et al. 2015); however, the study conducted by Piewngam et al. (2018) shows that the fengycins produced by B. subtilis ZK3814 (genotype NCIB3610) mediated Staphylococcus aureus exclusion effect in the human population by inhibiting $S$. aureus quorum sensing, a process through which bacteria respond to their population density by altering gene regulation.
Iturins are a class of lipopeptides produced by $B$. subtilis and $B$. amyloliquefasciens that are widely studied for their antiproliferative and antimicrobial properties. However, studies on antimicrobial activity of iturins are restricted to the biological control of phytopathogens, including phytopathogenic fungi and bacteria (Etchegaray et al. 2008; Arrebola et al. 2010; Zeriouh et al. 2011; Gong et al. 2015; Mora et al. 2015; Yamamoto et al. 2015; Cheng et al. 2016). To date, the number of studies that explore the therapeutic application of iturins is very low (Patel et al. 2015). In this way, this report is innovative in exploring the use of iturins and fengycins to control microbial pathogens involved in nosocomial infections.

\section{Biofilm dislodging assay}

Bacterial biofilms represent a concern in the hospital environment due to the resilience of chemical control. Besides, these structures are frequently involved in pathogen dissemination and hospital-acquired infections. As evident from Fig. 4, challenging the biofilms of A. xylosoxidans ATCC 13138, A. faecalis ATCC 8750, and P. alcaligenes ATCC 14909 with F4 lipopeptides dislodged the mature biofilms, and the extent of biofilm disruption was found to be concentration-dependent. Upon treatment at sub-MIC doses, biofilms of A. faecalis, A. xylosoxidans, and P. alcaligenes were dislodged by about 100,85 , and $81 \%$, respectively. Generally, the concentration of antimicrobial compounds necessary to damage sessile cells present in biofilms is much higher than the concentration required to be effective against planktonic cells. Overall, these results indicate that different factors may be responsible for the antimicrobial and antibiofilm activities of biosurfactants produced by strain TR47II.

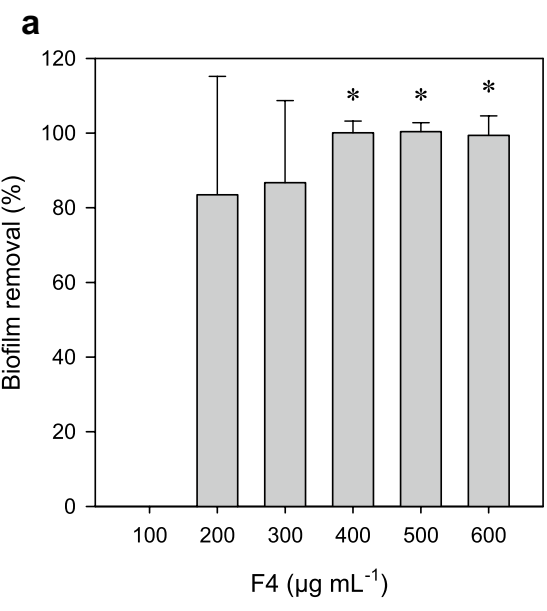

Fig. 4 Biofilm dislodging activity of chromatographic fraction F4 (100 to $600 \mu \mathrm{g} \mathrm{mL}^{-1}$ ) on biofilms of a Achromobacter xylosoxidans ATCC 13138, b Alcaligenes faecalis ATCC 8750, and c Pseudomonas alcaligenes ATCC 14909 on Mueller-Hinton broth. The
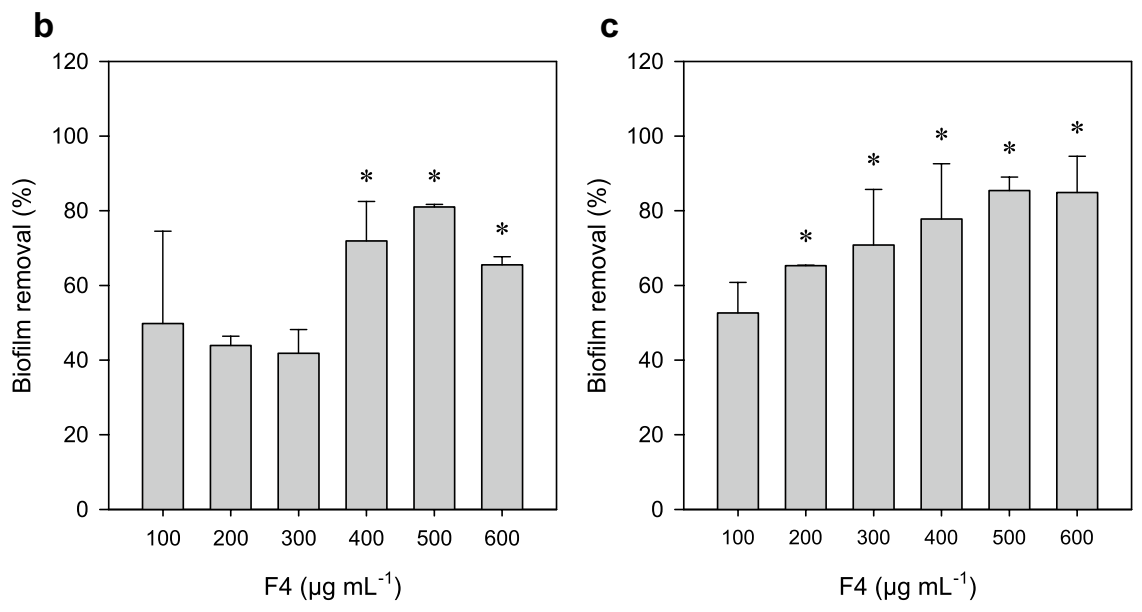

results are expressed as a percentage of biofilm removal relative to the non-treated control. Data was presented as mean \pm standard deviation of values obtained from three repetitions. Means followed by asterisks do not differ statistically by Tukey's test at $5 \%$ probability

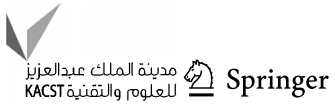


Fig. 5 Cell viability by MTT assay. a Vero and b MAC-T cells were treated with chromatographic fraction F4 (1 to $16 \times$ MIC) for $24 \mathrm{~h}$. The results were expressed as cell viability relative to the non-treated control. Data were presented as mean \pm standard deviation of values obtained from three repetitions

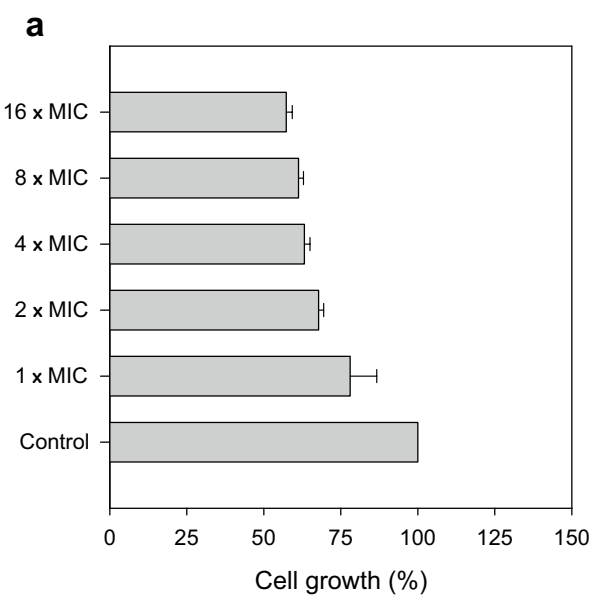

Biosurfactants are promising molecules for the inhibition of formation or removal of biofilms (Kiran et al. 2010), since many have antiadhesive and biofilm dislodging properties (Banat et al. 2014). Rautela et al. (2014) demonstrated that the extract containing fengycin and iturin produced by Bacillus amyloliquefaciens AR2 was able to remove biofilms of Candida albicans. Tabbene et al. (2015) demonstrated that bacillomycin D can remove biofilms of $C$. albicans in a concentration-dependent manner, with $90 \%$ of removal at a dose of $25 \mu \mathrm{g} \mathrm{mL}^{-1}$. Rivardo et al. (2009) demonstrated that fengycins produced by Bacillus sp. inhibit biofilm formation by E. coli CFT073 and S. aureus ATCC 29213 (97 and 90\%, respectively). Thus, the application of iturins and fengycins produced by B. subtilis TR47 II to abiotic surfaces can represent an effective strategy for reducing bacterial adhesion after biofilm formation.

\section{The cytotoxic effect on mammalian cells}

Regardless of the antimicrobial activity, toxicity tests constitute a crucial step to verify the safety use of B. subtilis TR47II for lipopeptide production and proposing these compounds as therapeutic agents. The results from the cytotoxic effect of F4 against mammalian cells is shown in Fig. 5. The chromatographic fraction F4 is non-cytotoxic at MIC (assumed value of $300 \mu \mathrm{g} \mathrm{mL}^{-1}$ ). There was no effect on the growth of MAC-T cells in a concentration equal to or less than $4 \times$ MIC. Upon this concentration, the growth was retained in approximately $37 \%$ relative to the control. Exposure of Vero cells to fraction F4 in a concentration equal to $\mathrm{MIC}$ reduced growth by $22 \%$ over control. However, the reduction of cell growth with increasing F4 concentration was less abrupt than that observed for MAC-T cells, maintaining approximately $57 \%$ growth in a concentration equal to $16 \times \mathrm{MIC}$ (equivalent to $4800 \mu \mathrm{g} \mathrm{mL}^{-1}$ ) (Fig. 5). As follows, the lipopeptides in F4 appear to be selective for bacterial membranes. Microbial biosurfactants are generally considered to be low toxicity or nontoxic compared to synthetic surfactants. They are, therefore, suitable for use in the pharmaceutical, cosmetic, and food industries (Nitschke and Costa 2007).

\section{Conclusion}

The lipopeptides from B. subtilis TR47II exhibit antibacterial and antibiofilm activity against the opportunists' pathogens. This activity was attributed to the fengycins and iturins, two lipopeptide categories that are underexplored as drug-leads compounds. Additionally, these molecules are non-cytotoxic to mammalians cells. Under the ability to inhibit planktonic growth and promote biofilm removal, two important traits involved in establishing nosocomial infections, the lipopeptides from strain TR47II may represent a potential candidate for developing drugs.

Acknowledgements We would like to Maria Aparecida Scatamburlo Moreira to providing the mammalians cells lines and the Laboratório de Doenças Bacterianas facilities for the conduction of the experiments.

Author contributions All the authors contributed to this work. FSF performed the experiments, analyzed the data, and wrote the paper; BALA and TCAL participated in the biosurfactant production, purification, and chemical characterization; TPS and MB participated in the antimicrobial and cytotoxicity experiments and data analysis; MRT supported and guided the experiments and revised the text. All authors reviewed and approved the manuscript.

Funding This work was supported by the Conselho Nacional de Desenvolvimento Científico e Tecnológico (CNPq) and the Federal Agency Coordenação de Aperfeiçoamento de Pessoal de Nível Superior (CAPES).

\section{Compliance with ethical standards}

Conflict of interest The authors declare that they have no conflict of interest. 
Ethical approval This article does not contain any studies with human participants or animals performed by any of the authors.

\section{References}

Arrebola E, Jacobs R, Korsten L (2010) Iturin A is the principal inhibitor in the biocontrol activity of Bacillus amyloliquefaciens PPCB004 against postharvest fungal pathogens. J Appl Microbiol 108:386-395. https://doi.org/10.1111/j.1365-2672.2009.04438.x

Banat IM, De Rienzo MAD, Quinn GA (2014) Microbial biofilms: biosurfactants as antibiofilm agents. Appl Microbiol Biotechnol 98:9915-9929. https://doi.org/10.1007/s00253-014-6169-6

Barragán EP, Pérez JS, Corbella L et al (2018) Achromobacter xylosoxidans bacteremia: clinical and microbiological features in a 10 year case series. Rev Esp Quimioter 31:268-273

Cheng J, Jaiswal KS, Yang SH, Suh J-W (2016) Endophytic Bacillus subtilis MJMP2 from Kimchi inhibits Xanthomonas oryzae pv. oryzae, the pathogen of rice bacterial blight disease. J Appl Biol Chem 59:149-154. https://doi.org/10.3839/jabc.2016.027

Cochrane SA, Vederas JC (2016) Lipopeptides from Bacillus and Paenibacillus spp.: a gold mine of antibiotic candidates. Med Res Rev 36:4-31. https://doi.org/10.1002/med.21321

da Silva FSP, Pylro VS, Fernandes PL et al (2015) Unexplored Brazilian oceanic island host high salt-tolerant biosurfactant-producing bacterial strains. Extremophiles 19:561-572. https://doi. org/10.1007/s00792-015-0740-7

Daas MS, Acedo JZ, Rosana ARR et al (2018) Bacillus amyloliquefaciens ssp. plantarum F11 isolated from Algerian salty lake as a source of biosurfactants and bioactive lipopeptides. FEMS Microbiol Lett 365:fnx248. https://doi.org/10.1093/femsle/fnx248

Etchegaray A, De Castro BC, De Melo IS et al (2008) Effect of a highly concentrated lipopeptide extract of Bacillus subtilis on fungal and bacterial cells. Arch Microbiol 190:611-622. https:// doi.org/10.1007/s00203-008-0409-z

Gong AD, Li HP, Yuan QS et al (2015) Antagonistic mechanism of iturin a and plipastatin a from Bacillus amyloliquefaciens S76-3 from wheat spikes against Fusarium graminearum. PLoS ONE 10:1-18. https://doi.org/10.1371/journal.pone.0116871

Hasan MJ, Nizhu LN, Rabbani R (2019) Bloodstream infection with pan drug-resistant Alcaligenes faecalis treated with double-dose of tigecycline. IDCases 18:e00600. https://doi.org/10.1016/j. idcr.2019.e00600

Kiran GS, Sabarathnam B, Selvin J, Selvin CJ (2010) Biofilm disruption potential of a glycolipid biosurfactant from marine Brevibacterium casei. Immunol Med Microbiol 59:432-438. https://doi. org/10.1111/j.1574-695X.2010.00698.x

Le Maire M, Champeil P, Møller JV (2000) Interaction of membrane proteins and lipids with solubilizing detergents. Biochim Biophys Acta: Biomembr 1508:86-111. https://doi.org/10.1016/S0304 $-4157(00) 00010-1$

Loiseau C, Schlusselhuber M, Bigot R et al (2015) Surfactin from Bacillus subtilis displays an unexpected anti-Legionella activity. Appl Microbiol Biotechnol 99:5083-5093. https://doi. org/10.1007/s00253-014-6317-z

Mandal SM, Barbosa AED, Franco OL (2013) Lipopeptides in microbial infection control: scope and reality for industry. Biotechnol Adv 31:338-345. https://doi.org/10.1016/j.biotechadv .2013.01.004

Mora I, Cabrefiga J, Montesinos E (2015) Cyclic lipopeptide biosynthetic genes and products, and inhibitory activity of plantassociated Bacillus against phytopathogenic bacteria. PLoS ONE 10:1-21. https://doi.org/10.1371/journal.pone.0127738
Morikawa M, Hirata Y, Imanaka T (2000) A study on the structurefunction relationship of lipopeptide biosurfactants. Biochim Biophys Acta: Mol Cell Biol Lipids 1488:211-218. https://doi. org/10.1016/S1388-1981(00)00124-4

Moryl M, Spetana M, Dziubek K et al (2015) Antimicrobial, antiadhesive and antibiofilm potential of lipopeptides synthesized by Bacillus subtilis, on uropathogenic bacteria. Acta Biochim Pol 62:725-732. https://doi.org/10.18388/abp.2015_1120

Nasompag S, Dechsiri P, Hongsing N et al (2015) Effect of acyl chain length on therapeutic activity and mode of action of the CXKYR-NH $\mathrm{N}_{2}$ antimicrobial lipopeptide. Biochim Biophys Acta: Biomembr 1848:2351-2364. https://doi.org/10.1016/j.bbame m.2015.07.004

Ndlovu T, Rautenbach M, Vosloo JA et al (2017) Characterisation and antimicrobial activity of biosurfactant extracts produced by Bacillus amyloliquefaciens and Pseudomonas aeruginosa isolated from a wastewater treatment plant. AMB Express 7:108. https:// doi.org/10.1186/s13568-017-0363-8

Nitschke M, Costa SGVAO (2007) Biosurfactants in food industry. Trends Food Sci Technol 18:252-259. https://doi.org/10.1016/j. tifs.2007.01.002

O'Neill J (2014) Antimicrobial resistance: tackling a crisis for the health and wealth of nations. Rev Antimicrob Resist. https://doi. org/10.1038/510015a

Patel H, Tscheka C, Edwards K et al (2011) All-or-none membrane permeabilization by fengycin-type lipopeptides from Bacillus subtilis QST713. Biochim Biophys Acta: Biomembr 1808:2000-2008. https://doi.org/10.1016/j.bbamem.2011.04.008

Patel S, Ahmed S, Eswari JS (2015) Therapeutic cyclic lipopeptides mining from microbes: latest strides and hurdles. World J Microbiol Biotechnol 31:1177-1193. https://doi.org/10.1007/s1127 4-015-1880-8

Pathak KV, Keharia H (2014) Identification of surfactins and iturins produced by potent fungal antagonist Bacillus subtilis $\mathrm{K} 1$ isolated from aerial roots of banyan (Ficus benghalensis) tree using mass spectrometry. 3 Biotech 4:283-295. https://doi.org/10.1007/s1320 5-013-0151-3

Piewngam P, Zheng Y, Nguyen TH et al (2018) Pathogen elimination by probiotic Bacillus via signalling interference. Nature 562:532537. https://doi.org/10.1038/s41586-018-0616-y

Rautela R, Singh AK, Shukla A, Cameotra SS (2014) Lipopeptides from Bacillus strain AR2 inhibits biofilm formation by Candida albicans. Antonie van Leeuwenhoek Int J Gen Mol Microbiol 105:809-821. https://doi.org/10.1007/s10482-014-0135-2

Rivardo F, Turner RJ, Allegrone G et al (2009) Anti-adhesion activity of two biosurfactants produced by Bacillus spp. prevents biofilm formation of human bacterial pathogens. Appl Microbiol Biotechnol 83:541-553. https://doi.org/10.1007/s00253-009-1987-7

Romero D, Vicente AD, Rakotoaly RH et al (2007) The iturin and fengycin families of lipopeptides are key factors in antagonism of Bacillus subtilis toward Podosphaera fusca. Mol Plant Microbe Interact 20:430-440. https://doi.org/10.1094/MPMI-20-4-0430

Tabbene O, Di Grazia A, Azaiez S et al (2015) Synergistic fungicidal activity of the lipopeptide bacillomycin D with amphotericin B against pathogenic Candida species. FEMS Yeast Res 15:fov022. https://doi.org/10.1093/femsyr/fov022

Tagliabue A, Rappuoli R (2018) Changing priorities in vaccinology: antibiotic resistance moving to the top. Front Immunol 9:1068. https://doi.org/10.3389/fimmu.2018.01068

Tran TT, Munita JM, Arias CA (2015) Mechanisms of drug resistance: daptomycin resistance. Ann N Y Acad Sci 1354:32-53. https:// doi.org/10.1111/nyas. 12948

Treviño M, Moldes L, Hernández M et al (2010) Nosocomial infection by VIM- 2 metallo- $\beta$-lactamase-producing Pseudomonas putida. J Med Microbiol 59:853-855. https://doi.org/10.1099/jmm.0.01803 $6-0$

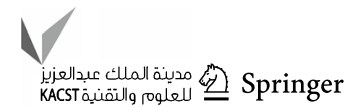


Wei L, Lu J, Xu H et al (2015) Silver nanoparticles: synthesis, properties, and therapeutic applications. Drug Discov Today 20:595601. https://doi.org/10.1016/j.drudis.2014.11.014

World Health Organization (2016) United Nations meeting on antimicrobial resistance. Bull World Health Organ 94:638-639. https:// doi.org/10.2471/BLT.16.020916

World Health Organization (2018) WHO I antibiotic resistance. In: antibiotic resistance fact sheet. https://www.who.int/news-room/ fact-sheets/detail/antibiotic-resistance

Xu BH, Ye ZW, Zheng QW et al (2018) Isolation and characterization of cyclic lipopeptides with broad-spectrum antimicrobial activity from Bacillus siamensis JFL15. 3 Biotech 8:444. https://doi. org/10.1007/s13205-018-1443-4

Yamamoto S, Shiraishi S, Kawagoe Y et al (2015) Impact of Bacillus amyloliquefaciens S13-3 on control of bacterial wilt and powdery mildew in tomato. Pest Manag Sci 71:722-727. https:// doi.org/10.1002/ps.3837

Yang H, Li X, Li X et al (2015) Identification of lipopeptide isoforms by MALDI-TOF-MS/MS based on the simultaneous purification of iturin, fengycin, and surfactin by RP-HPLC. Anal Bioanal Chem 407:2529-2542. https://doi.org/10.1007/s0021 6-015-8486-8

Zeriouh H, Romero D, Garcia-Gutierrez L et al (2011) The iturin-like lipopeptides are essential components in the biological control arsenal of Bacillus subtilis against bacterial diseases of cucurbits. Mol Plant Microbe Interact 24:1540-1552. https://doi. org/10.1094/MPMI-06-11-0162 